\title{
Ludwik Brożek (1907-1976), pseud. i krypt.: Kurzelowski Jan, L.B., B.L., Ib, B.; przydomki: „Śląski Estreicher”, „Śląski Korbut"; bibliograf, bibliotekarz, kustosz muzeum, historyk kultury i literatury Śląska Cieszyńskiego
}

Urodził się 25 sierpnia 1907 roku w Karwinie (obecnie Czechy) na Śląsku Cieszyńskim. Był synem Franciszka, górnika pochodzącego z emigracji zarobkowej z wioski Zbydniowice pod Krakowem, który w 1888 roku ożenił się z Florentyną z domu Iwan z Karwiny. Małżeństwo miało dziesięcioro dzieci, spośród których dwoje zmarło w dzieciństwie. Najmłodszy Ludwik został osierocony w jedenastym roku życia. Po ukończeniu szkoły ludowej w Karwinie jego starszy brat Karol (1897-1968) umieścił Ludwika w 1919 roku w bursie Gimnazjum Realnego im. Juliusza Słowackiego w Orłowej i nakładał na jego kształcenie. Po podziale Śląska Cieszyńskiego w 1921 roku Ludwik przeszedł do Gimnazjum MatematycznoPrzyrodniczego im. Antoniego Osuchowskiego w Cieszynie, gdzie w 1927 roku otrzymał świadectwo dojrzałości. Podjął studia teologiczne w Uniwersytecie Jagiellońskim, ale po roku zrezygnował i przeniósł się na studia polonistyczne do Państwowego Pedagogium w Krakowie, które ukończył w 1930 roku z dyplomem nauczyciela szkół podstawowych. Uczestniczył w życiu Stowarzyszenia Akademików Polaków na Śląsku Cieszyńskim „Znicz”, będąc przez pewien czas sekretarzem koła krakowskiego.

Debiutował jako student artykułem polemicznym Kilka uwag z powodu artykułu J. Przybyty. Twórczość literacka młodego Ślazaka („Polska Zachodnia” 1929, nr 20). Zachęcony przez swojego nauczyciela ks. Józefa Londzina od 1926 roku zajmował się bibliografią. Opublikował O bibliografii cieszyńskiej i rzeczach 
pokrewnych („Zaranie Śląskie” 1930, z. 1). Należał do kilku pionierów śląskiej bibliografii.

W 1930 roku podjął pracę nauczyciela w Skoczowie, gdzie pracował Gustaw Morcinek, który wprowadził Brożka do Koła Literatów na Śląsku. Od 1931 roku kontynuował pracę nauczyciela w Cieszynie. W 1935 roku podjął pracę adiunkta w Bibliotece Sejmu Śląskiego w Katowicach (późniejsza Biblioteka Śląska), a 1 kwietnia 1939 roku — kustosza Muzeum Miejskiego w Cieszynie. Od 1930 roku był członkiem komitetu redakcyjnego, a od 1935 roku sekretarzem redakcji „Zarania Śląskiego" - organu Polskiego Towarzystwa Ludoznawczego w Cieszynie. W 1937 roku został sekretarzem Sekcji Bibliofilskiej przy Kole Śląskim Związku Bibliotekarzy Polskich. Z Oskarem Michejdą z Trzyńca opublikowali artykuł Powojenna prasa polska na Ślasku Cieszyńskim (w: „Roczniki Towarzystwa Przyjaciół Nauk na Śląsku" 1934, t. IV, s. 217-230). Bibliografia obejmowała 80 czasopism po stronie polskiej, którą zestawił Brożek, a po stronie czeskiej 41. Związał się z katowickim środowiskiem literackim skupionym wokół czasopism „Kuźnica” i „Fantana”. Publikował artykuły historyczno- i krytycznoliterackie, m.in. w: „Zaraniu Śląskim”, „Gwiazdce Cieszyńskiej”, „Kuźnicy” i „Powstańcu Śląskim". Opublikował bibliografie osobowe, m.in.: ks. Józefa Londzina (1933), ks. Oskara Zawiszy (1933), Franciszka Popiołka (1938). Wraz z Martą Pampuch i Jackiem Koraszewskim był członkiem Komitetu Redakcyjnego Bibliografii Śląskiej przy Bibliotece Sejmu Śląskiego w Katowicach, który opracowywał „Wykaz Literatury Bieżącej o Śląsku”, (r. 1-5, Wydawnictwo Instytutu Śląskiego w Katowicach, Katowice 1935-1939). W 1939 roku dorobek opublikowany Brożka liczył 91 pozycji.

Podczas okupacji niemieckiej pracował jako robotnik budowlany w Karwinie, a od 1943 roku - robotnik transportowy w Cieszynie. Bał się o swojego brata Rudolfa (1901—1948), sztygara w Łazach na Zaolziu, który był więźniem niemieckiego obozu koncentracyjnego w Dachau. Jego przyjaciel Paweł Musioł (1905-1943), pochodzący z Zaolzia, historyk i krytyk literacki, członek ruchu oporu, dnia 19 lutego 1943 roku został zgilotynowany przez Niemców w więzieniu w Katowicach. Z kolei inny przyjaciel, Gustaw Morcinek (1891 - 1963), był więziony w niemieckich obozach koncentracyjnych m.in. w Sachsenhausen i Dachau.

W 1945 roku Brożek wrócił na przedwojenne stanowisko kustosza Muzeum Miejskiego w Cieszynie. Zabezpieczył rozproszone przez Niemców zbiory muzealne i księgozbiory, które stale pomnażał. Utworzono też cieszyński Oddział Zabytkowy Biblioteki Śąskiej w Katowicach, którego od 1960 roku aż do śmierci był kierownikiem, równocześnie do 1971 roku pozostając kustoszem Muzeum. O swoich miejscach pracy pisał m.in. w: Z moich wspomnień o „Zaraniu Ślaskim” („Zaranie Śląskie” 1967, z. 2, s. 229-240); Z dziejów muzealnictwa w Cieszynie (w: „Rocznik Muzeum Górnośląskiego w Bytomiu”. Historia, Bytom 1963, z. 1, s. 15-45); Zbiory Cieszyńskie. Oddziat Zabytkowy w Cieszynie (w: Biblioteka Ślaska 1922-1972, Katowice 1973, s. 67-83, 250-251, 306-307).

W 1956 roku podjął studia w Uniwersytecie Wrocławskim w Studium Zaocz-

284 nym Wydziału Filologicznego, na kierunku bibliotekoznawstwo. Po pierwszym 
semestrze zrezygnował z powodu odległości do Wrocławia i stanu zdrowia. Po uznaniu dyplomu z Państwowego Pedagogium w Krakowie za ukończenie studiów wyższych (Ustawa z dnia 9 sierpnia 1965 r. o stopniach i tytułach naukowych), w 62. roku życia, dnia 18 lutego 1969 roku w Uniwersytecie Wrocławskim uzyskał stopień doktora nauk humanistycznych na podstawie dysertacji Folklor cieszyński i jego odbicie w regionalnej kulturze i literaturze Ślaska Cieszyńskiego. Zagadnienia wybrane (promotor: prof. Bogdan Zakrzewski, recenzenci: prof. Julian Krzyżanowski i doc. Józef Ligęza). W tymże roku uzyskał stopień bibliotekarza dyplomowanego, a w 1971 roku nominację na kustosza dyplomowanego.

Brożek zamiłowanie do książek wyniósł $\mathrm{z}$ domu rodzinnego. Rodzeństwo wspominało, że zabawą Ludwiczka było układanie książek, pewnie niewielu w górniczym familoku, jak określano wielorodzinny dom górniczy. W gimnazjum pracował w Bibliotece Macierzy Szkolnej, porządkując księgozbiór Józefa Ignacego Kraszewskiego. Gromadził prywatny księgozbiór, który stracił w 1939 roku. Po wojnie ponownie budował domowy księgozbiór. W Muzeum Miejskim w Cieszynie rozbudował księgozbiór, który w 1960 roku wyodrębniono w Oddział Zabytkowy Biblioteki Śląskiej w Cieszynie, liczący 50 tysięcy woluminów. Na Bibliotekę złożyły się księgozbiory: Józefa Ignacego Kraszewskiego, Tadeusza Regera, Czytelni Ludowej, Towarzystwa Ludoznawczego i inne. Pracował nad inwentaryzacją. Opublikował Silesiaca w Bibliotece Muzeum w Cieszynie (1957, druk powielony). Uczestniczył w rewindykacji w 1962 roku biblioteki Leopolda Szersznika, którą Niemcy wywieźli i która po wojnie odnalazła się w Pradze. Księgozbioru Dziedzictwa błogosławionego Jana Sarkandra nie odnaleziono, przepadł podczas okupacji niemieckiej. Jeszcze w przeddzień śmierci Brożek dwukrotnie przenosił paczki książek z Czeskiego Cieszyna do Biblioteki w Cieszynie.

W 1947 roku opublikował artykuł Bibliografia Ślaska za lata 1945-1946 („Zaranie Śląskie” 1947, z. 1/2). Była to kontynuacja przedwojennego „Wykazu Literatury Bieżącej na Śląsku". Kontynuował publikacje bibliografii osobowych, m.in.: Józefa Lompy (1947), Gustawa Morcinka (1954, 1961), Jana Wantuły (1956), Józefa Ligęzy (1973), Romana Lutmana (1973), Alojzego Targa (1974), Karola Piegzy (1974). Publikował bibliografie osobowe pozaregionalne, m.in.: Bibliografia Kopernikowska za lata 1923 - 1948 (1949), Zofii Kossak (1957), Jana Dzierżonia (1961). Był autorem 29 bibliografii osobowych, poza tym bibliografii miast Cieszyna i Wisły oraz piśmiennictwa, pamiętników, prasy polskiej na Śląsku Cieszyńskim i innych. Około 30 różnych zestawień bibliograficznych zostało w rękopisie. Stworzył kartotekę bio-bibliograficzną, która liczyła około 60 tysięcy zapisów (fiszek). Była narzędziem pracy bibliograficznej i biograficznej Brożka. Przy Bibliotece funkcjonowało nieformalne centrum naukowych badań historii i kultury Śląska Cieszyńskiego. Z kartoteki Brożka korzystali liczni studenci, magistranci, doktoranci, pracownicy naukowi, pisarze i miłośnicy regionu.

Brożek znajdował się wśród pionierów biografistyki śląskiej, którzy jeszcze przed 1939 rokiem rozpoczęli pracę nad Śląskim słownikiem biograficznym, którego I tom ukazał się w 1977 roku, II w 1979 roku, III w 1981 roku; opublikowano w nich pośmiertnie sześć biografii autorstwa Brożka. Współpracował 
z Polskim stownikiem biograficznym, w którym w latach 1947-1974 ukazało się 38 biografii Brożka. Był autorem cyklu Sylwetki naszych działaczy oraz Sylwetki naszego regionu w zaolziańskim „Zwrocie” w latach 1966-1974, obejmującym 25 postaci. Do czasopism i kalendarzy pisał biograficzne artykuły okolicznościowe, rocznicowe, wspomnieniowe i pośmiertne.

Uczestniczył w XXXIII Walnym Zgromadzeniu Polskiego Towarzystwa Ludoznawczego w dniach 19-21 kwietnia 1958 roku w Cieszynie, na którym wygłosił referat Tradycje ludoznawcze na Śląsku Cieszyńskim. Był jednym z założycieli i członkiem Sekcji Folklorystycznej przy Zarządzie Głównym Polskiego Związku Kulturalno-Oświatowego (PZKO) w Czechosłowacji w Czeskim Cieszynie. W Stowniku folkloru polskiego pod redakcją Juliana Krzyżanowskiego (Warszawa 1965) był autorem haseł dotyczących Śląska Cieszyńskiego. Do słownika folkloru cieszyńskiego, którego nie zrealizował, pozostawił w rękopisie zestaw haseł. Folklorystyka była tematem pracy doktorskiej Brożka, w której ujął część swojego dorobku w tym zakresie. W pracy przedstawił następujące rozdziały: Rodowód folkloru cieszyńskiego; Tradycje ludoznawcze na Ślasku Cieszyńskim; Z dziejów muzealnictwa w Cieszynie; Z dziejów „,Zarania Śląskiego"; Ondrasciana; Dokumenty zbójnickie; Pisarze ludowi ziemi cieszyńskiej; Jan Wantuła; Jerzy Probosz; Kalendarze cieszyńskie. Poza wymienionymi tematami w dorobku Brożka o folklorze mieszczą się artykuły o: pieśniach ludowych, podaniach, bajkach, zwyczajach, strojach, architekturze i sztuce. W pracy Daniela Kadłubca z zespołem, Plyniesz Olzo. Monografia kultury ludowej Śląska Cieszyńskiego (Czeski Cieszyn 2016), autorem dwóch rozdziałów był Brożek: Źródła kultury ludowej (s. 23-32) i Cieszyńscy pisarze ludowi (s. 95-116).

W 1954 roku pod redakcją Brożka ukazała się książka Śląsk (Wydawnictwo Sport i Turystyka, Warszawa 1954, stron 184). W „Głosie Ziemi Cieszyńskiej” (1955, nr 1-6; 1956, nr 2-7) publikował cykl Cieszyńskie okruchy historyczne. W zaolziańskim „Zwrocie” ogłosił dwa cykle artykułów — Poetyckie wzloty (1957, nr 1-12) i Pod szyndziołami (1958, nr 1, 2, 6, 9, 10) — poświęcone cieszyńskiemu ruchowi literackiemu i wydawniczemu. Wraz z Gwido Chmarzyńskim i Mieczysławem Gładyszem był współautorem rozdziału Region cieszyński (w: Górny Ślask, red. K. Popiołek et al., Poznań 1959, s. 362 - 497, 512-515). Był redaktorem i wydawcą następujących prac: Jan Wantuła: ksiażki i ludzie. Szkic o wydawnictwach i piśmiennictwie na Ślasku Cieszyńskim (1956); Wspomnienia Cieszyniaków (1964), do których dołączył 28 biogramów autorów oraz bibliografię pamiętników cieszyńskich do roku 1918, obejmujących 176 pozycji; Wincenty Ogrodziński, Dzieje piśmiennictwa ślaskiego (1965, współautor Zdzisław Hierowski), gdzie uzupełnił zestaw bibliograficzny oraz hasła w słowniku biograficznym pisarzy śląskich; Paweł Musioł, Piśmiennictwo polskie na Ślasku do poczatku XIX wieku (1970). Jako członek komitetu redakcyjnego cyklu powieści historycznych Kraszewskiego opracował wydania: Bialy Książe (1955, 1960, 1970), Pamiętnik Mroczka (1957), Historia prawdziwa o Petrku Właście palatynie, którego zwano Duninem (1959); opracował: Gustaw Morcinek, Wyrąbany chodnik (1947), Z mojej ziemi (1955). 
W antologii Pisarze ślascy XIX i XX wieku pod redakcją Zdzisława Hierowskiego (1963) napisał biografie autorów i dokonał wyboru ich utworów: Pawet Stalmach, Jan Kubisz, Jan Łysek, Jan Wantuła, Jerzy Probosz oraz był autorem rozdziału Piśmiennictwo na Ślasku Cieszyńskim (s. 95-106) i Bibliografii (s. 109-111). Wspólnie z H. Rechowiczem, Alojzym Targiem, R. Hajdukiem opublikowali Materiaty do listy strat kultury polskiej na Śląsku w latach 1939-1945 (,Zaranie Śląskie” 1960, z. 4; Brożek opracował straty na Śląsku Cieszyńskim). W monografii Cieszyn. Zarys rozwoju miasta i powiatu pod redakcją Józefa Chlebowczyka (Katowice 1973) był autorem rozdziału Wiek XIX (s. 169-228). Publikował także w języku czeskim, np. Školství v Těšinském Slezsku v druhě polovině XIX století („Slezský Sborník” 1960, nr 4, s. 516-526); tłumaczył z czeskiego na język polski, np. J. Valenta, Wywrotowa polityka mniejszości niemieckiej w Czechosłowacji w latach 1918-1938 (wydane w serii Biuletynów Śląskiego Instytutu Naukowego w Katowicach, 1961, nr 27).

Dorobek pisarski Brożka obejmuje ponad 500 pozycji dotyczących literatury, historii, kultury, folklorystyki i sztuki Śląska Cieszyńskiego. Są to: opracowania, bibliografie, biografie, szkice, artykuły przyczynkarskie, polemiki, sprawozdania, słowa wstępne i posłowia oraz recenzje w czasopismach, pamiętnikach, słownikach, kalendarzach i pozycjach książkowych. Wchodził w skład rad i komitetów redakcyjnych czasopism: „Zaranie Śląskie”, „Głos Ziemi Cieszyńskiej”, „Cieszyński Rocznik Muzealny”, „,Rocznik Cieszyński”, „Pamiętnik Cieszyński”, „Biuletyn Informacyjny Biblioteki Śląskiej”. Publikował m.in. w „Kwartalniku Opolskim”, „Odrze”, „Poglądach”, „Głosie Ludu”, „Zwrocie”, „Biuletynie Ludoznawczym PZKO”, jak również w czasopismach pozaregionalnych, m.in. w „Literaturze Ludowej” i „Przeglądzie Zachodnim”.

Brożek znany był z wielkiej służebności, pracowitości i skromności. Był członkiem Stowarzyszenia Bibliotekarzy Polskich, Polskiego Towarzystwa Historycznego, Śląskiego Towarzystwa Miłośników Książki, Macierzy Szkolnej Ziemi Cieszyńskiej, Komisji Bibliografii i Bibliotekoznawstwa Wrocławskiego Towarzystwa Naukowego, Komisji Etnograficznej PAN — Oddział w Krakowie oraz Komisji Historyczno-Literackiej przy Oddziale PAN w Katowicach. Współpracował z Sekcją Folklorystyczną PZKO w Czeskim Cieszynie. Należał do Stronnictwa Demokratycznego. Przez kilka kadencji był radnym Miejskiej Rady Narodowej w Cieszynie i ławnikiem Sądu Powiatowego tamże. Był popularyzatorem; wygłaszał prelekcje w Sekcji Folklorystycznej PZKO, Oddziale Cieszyńskim Polskiego Towarzystwa Historycznego, Klubie Propozycji w Cieszynie, Domu Kultury i Bibliotece Miejskiej w Ustroniu i Wiśle oraz Kole Przewodników przy Oddziale Polskiego Towarzystwa Turystyczno-Krajoznawczego w Cieszynie. Brał czynny udział w sesjach popularnonaukowych.

Zmarł nagle z powodu udaru mózgu dnia 7 czerwca 1976 roku w Cieszynie. Pochowany został pod kolumnadą „Miasto Cieszyn Zasłużonym” na Cmentarzu Komunalnym w Cieszynie, jako jeden z dziewięciu wybitnie zasłużonych, wśród m.in. ks. Józefa Londzina, Karola Miarki, Gustawa Morcinka i Pawła Stalmacha. 
Odznaczony był m.in.: Krzyżem Kawalerskim Orderu Odrodzenia Polski (1972), dwukrotnie Złotym Krzyżem Zasługi $(1958,1967)$ oraz Nagrodą Województwa Katowickiego w dziedzinie muzealnictwa (1964).

W małżeństwie (1935) z Antoniną Wicherek (1909-1997) z Łazów na Śląsku Cieszyńskim mieli syna Jana (1936 - 1995), sędziego w Cieszynie i Bielsku-Białej.

Prywatną bibliotekę Brożka, obejmującą 17 tysięcy pozycji, głównie silesianów, i część kartoteki bio-bibliograficznej zakupił Uniwersytet Śląski.

Bratanek Andrzej Brożek (1933 - 1994), prof. UJ wspominał: „Szkoda mi jego bezcennych zapisów bibliograficznych, które były dziełem jego życia, a o które obawiał się w rozmowie z Janem Brodą [(1911-2007) cieszyński etnograf i historyk - K.B.] jeszcze cztery dni przed śmiercią, »by nie dostały się na przemiał albo do pieca《” (J. Broda: Ostatnie spotkanie. „Zwrot” 1978, nr 7, s. 44-45). I stało się - po śmierci Brożka część pudeł z jego materiałami nowa kierowniczka Oddziału Zabytkowego Biblioteki Śląskiej przeznaczyła na makulaturę; wyrzucano je przez okno na dziedziniec Muzeum.

Pozostałości kartoteki bio-bibliograficznej Brożka znajdują się w Bibliotece Instytutu Bibliotekoznawstwa i Informacji Naukowej Uniwersytetu Śląskiego w Katowicach oraz w Książnicy Cieszyńskiej w Cieszynie. Korespondencje Brożka, około 2 tysiące listów, zgromadzono w Centrum Wiedzy o Regionie przy Zarządzie Głównym Macierzy Ziemi Cieszyńskiej w Cieszynie i w Książnicy Cieszyńskiej oraz w Zbiorach Specjalnych Biblioteki Śląskiej.

Księgozbiór Oddziału Zabytkowego w Cieszynie Biblioteki Śląskiej w Katowicach znajduje się w otwartej w 1994 roku Książnicy Cieszyńskiej, nowoczesnym warsztacie do badań bibliologicznych i regionalnych. Tym samym zrealizowano marzenia Brożka o stworzeniu ośrodka naukowego w Cieszynie, któremu dał początki.

Miasto Cieszyn uhonorowało Brożka ulicą jego imienia. W 90. rocznicę urodzin uczczono jego pamięć dnia 5 listopada 1997 roku w Cieszynie na konferencji popularnonaukowej zorganizowanej przez Zarząd Główny Macierzy Ziemi Cieszyńskiej. Pokłosiem konferencji jest książka Ludwik Brożek. Śląski Estreicher, praca zbiorowa pod redakcją Jadwigi Miękiny-Pindur (Cieszyn 1998). Biblioteka Śląska w Katowicach eksponowała w 2006 roku wystawę pt. Ludwik Brożek ślaski Estreicher, bibliograf, regionalista, publicysta.

\section{Wybór piśmiennictwa}

Bątkiewicz T., 2002: Polskie bibliografie regionalne ogólne od początku do 2002 roku (ze szczególnym uwzględnieniem bibliografii śląskich). Katowice: Biblioteka Śląska, s. $32,39,40,42,73$.

„Biuletyn Ludoznawczy”, 1978: zeszyt VIII poświęcony pamięci dra Ludwika Brożka, fot.

Broda J., Heller M., 1983: Bibliografia prac Ludwika Brożka. „Rocznik Cieszyński”, t. IV-V, s. $241-258$. 
Brożek A., 1979: Wujek Ludwik. „Kalendarz Śląski”, r. XIX, s. 65-70, fot.

Brożek K., 2021: Ludwik Brożek (1907-1976). W: Bibliotekarze i pracownicy książki województwa śląskiego. Red. M. Kycler, J. Sadowska. Warszawa: Wydawnictwo Naukowe i Edukacyjne SBP, s. 11-15, fot.

Chojnacki W., 1979: Dr Ludwik Brożek (1907-1976). „Roczniki Biblioteczne”, t. XXI, s. $1019-1924$.

Fazan M., 1979: Brożek Ludwik. W: Ślaski słownik biograficzny. T. 2. Red. J. Kantyka, W. Zieliński. Katowice: Śląski Instytut Naukowy, s. 32-36.

Fazan M., Nawrocki W., 1969: Katowickie środowisko literackie w latach 1945-1967. Katowice: Wydawnictwo „Śląsk”, s. 120-122, fot.

Golec J., Bojda S., 1993: Ludwik Brożek. W: Eidem: Słownik biograficzny Ziemi Cieszyńskiej. T. 1. Cieszyn: nakł. autorów, s. 46-47.

Grobelny A., 1976: Za Ludwikiem Brożkiem. Těšínsko. Vlastivědný zpravozdaj okresů Karviná a Frýdek-Mistek, nr 4.

Heska-Kwaśniewicz K., 1991: O śląskim Estreicherze - Ludwiku Brożku. „Gość Niedzielny", Katowice 24.11.1991, nr 47, s. 8, fot.

Lubos A., 1974: Geschichte der Literatur Schlesiens. 3 Band. München: Bergstadtverlag W.G. Korn, s. 559-560.

Między Cieszynem a Krakowem. Młodzieńcza korespondencja Ludwika Brożka do brata 1924-1930, 1979. Przygotował do druku i wstępem opatrzył A. Brożek. Opole: Instytut Śląski, fot.

Miękina L., Rosner E., 1976: Stu pisarzy cieszyńskich. Słownik bio- i bibliograficzny. „Rocznik Cieszyński”, t. III, s. 161-162.

Miękina-Pindur J., 2001: Ludwik Brożek — „Śląski Estreicher”. Sylwetka bibliografa, bibliofila i regionalisty. Katowice: Gnome, fot.

Miękina-Pindur J., red., 1998: Ludwik Brożek „Śląski Estreicher”. Cieszyn: Macierz Ziemi Cieszyńskiej, fot.

Rozner E., 1994: Brożek Ludwik. W: Słownik badaczy literatury polskiej. T. 1. Red. J. Starnawski. Łódź: Wydawnictwo Uniwersytetu Łódzkiego, s. 42-46.

Rozner E., 2013: Brożek Ludwik. W: Leksykon Polaków w Republice Czeskiej i Republice Słowackiej. T. 2. Red. Z. Jasiński, B. Cimała. Opole: Instytut Nauk Pedagogicznych Uniwersytetu Opolskiego, s. 28-29, fot.

Rzadkowska M., 2010: Brożek Ludwik. W: Słownik pracowników książki polskiej. Supl. 3. Red. H. Tadeusiewicz. Warszawa: Wydawnictwo Stowarzyszenia Bibliotekarzy Polskich, s. 28-30.

Słownik współczesnych pisarzy polskich. T. 4, 1966. Warszawa: Państwowe Wydawnictwo Naukowe, s. 12-13.

Snoch B., 2004: Górnośląski leksykon biograficzny. Katowice: Muzeum Śląskie, s. 46.

Szewczyk W., 1976: Drogi niezapomniany Ludwiczek. „Dziennik Zachodni”, Katowice 1.08.1976, nr 149, s. 3.

Szymiczek F., 1978: Ludwik Brożek (1907-1976). „Studia Śląskie. Seria Nowa”, t. 33, s. $199-211$.

Wieczorek U., 2007: Ludwik Brożek. W: Etnografowie i ludoznawcy polscy. Sylwetki, szkice biograficzne. T. 2. Red. E. Fryś-Pietraszkowa, A. Spiss. Wrocław-Kraków: Polskie Towarzystwo Ludoznawcze, Oddział Polskiego Towarzystwa Ludoznawczego, s. $30-32$,

Wielka encyklopedia powszechna PWN. T. 4, 2001. Warszawa: Wydawnictwo Naukowe PWN, s. 482. 